Article

\title{
Multivariable Supplier Segmentation in Sustainable Supply Chain Management
}

\author{
Gregorio Rius-Sorolla * (D), Sofía Estelles-Miguel * and Carlos Rueda-Armengot \\ Dpto. de Organización de Empresas. Universitat Politècnica de València, Camino de Vera s/n, \\ 46022 Valencia, Spain; crueda@doe.upv.es \\ * Correspondence: greriuso@upv.es (G.R.-S.); soesmi@omp.upv.es (S.E.-M.)
}

Received: 3 April 2020; Accepted: 1 June 2020; Published: 3 June 2020

check for updates

\begin{abstract}
Pressure from stakeholders for sustainable development is forcing top management to reconsider its supply chain management. This form of sustainability must consider the risks, insecurities, and lack of proximity caused by any event on the global economy. Organizations must identify and manage the risks of every link in the chain, while pursuing sustainable development. Corporate social responsibility (CSR) and sustainable development must be the result of a deliberate and coordinated response by the entire organization. A suitable segmentation of suppliers allows development strategies to be prioritized. This article presents the steps that should be followed in supply chain management, the identification of risks, and the new leadership of purchasing management to develop a sustainable supply chain. To this end, some of the key industrial actions reported in the literature are outlined, and two case studies are presented to identify the steps for the segmentation and dynamic development of suppliers. This article provides reflections on the responsibilities of senior management in the new era of sustainable development and presents guidance on how to coordinate sustainable development in the supply chain.
\end{abstract}

Keywords: sustainability; supply chain management; corporate social responsibility; segmentation; purchasing

\section{Introduction}

Once the necessary levels of efficiency in supplier selection have been guaranteed, the next step for a company to be competitive is to ensure that the supply chain can contribute meaningfully to the products and services that the company offers while adhering to its sustainability policies. These policies must refer to social sustainability as well as environmental sustainability, thus achieving the approval of different stakeholders [1].

Accordingly, the company requirements are on three levels, as described in the model proposed by Joyce et al. [2]. Each is indispensable for the business to function correctly. These levels are the economic level, where the relationship with stakeholders is materialized in markets; the social level, where relationships with suppliers, customers, and the community must be based on trust and the fulfillment of social objectives; and the level of environmental sustainability, where empirical evidence and the discourse of climate change experts has generated a new consumer culture that leads companies toward changes in their behavior, thus improving how they are received by markets. A complete conceptual map of company requirements is presented in Figure 1.

The importance of the supply chain in achieving sustainability and competitiveness in markets is huge, as reflected by multiple approaches in the management literature. Among those approaches are the resource-based view (RBV), the dynamic capabilities view (DCV), and the view based on supply chain management (SCM) as a catalyst that generates value through interorganizational relationships with suppliers. In the first case, the mix of resources, including relationships with suppliers, has a 
high level of fit [3,4]. Here, idiosyncratic characteristics [5] guarantee a competitive advantage. In the second case, the DCV introduces flexibility in the bundle of resources [6,7], making it more manageable and adaptable to the company's policies and strategies. Finally, authors such as Gold et al. [8] and Walker et al. [9] have emphasized the resources and economies of specialization of suppliers, and the sustainability advantages that can be obtained from their cooperation with the main company.

When the institutions of a society are considered as the sum of its legal framework, its most important organizations, and its citizens' culture [10,11], changes in the latter in relation to social and environmental sustainability will affect companies in areas ranging from sales strategies to models of supply and production. This fits perfectly with the ideas of the founders of corporate social responsibility (CSR) $[12,13]$, for whom the costs that the company incurs to adapt to the wishes of stakeholders improve its image in the markets and its income. As a consequence, this may improve its profits.

Social and/or environmental improvements are "good" for the company because they serve the requirements of the stakeholders and indirectly drive economic improvement (Figure 1). These improvements may involve economic improvement, as well as social or environmental improvement, and are therefore "better." Furthermore, certain projects combine economic, social, and environmental improvements. For example, ultrasonic cleaning versus the use of solvents has reduced process costs, improved environmental friendliness, and enhanced worker safety. It has become sustainable.

Sustainability management should begin with purchase management. The need to buy from suppliers certified with ISO 9001 is assumed. It should also be assumed that companies will work with suppliers that ensure the sustainability of their products and services in order to outperform competitors [14,15]. The World Commission on Environment and Development defines sustainable development as a kind of development that meets the needs of the present without compromising the ability of future generations to meet their own needs [16,17]. Akhavan et al. [18] recommended the evaluation of suppliers using the triple bottom line perspective for sustainability. The components are defined with the sustainable development objectives of United Nations Economic and Social Council [19]. They include economic considerations (including the promotion of economic growth, logistic efficiency, and the achievement of good quality levels), environmental considerations (including reductions in resource use and the protection of the natural environment), and social dimensions (including the creation of productive employment and the achievement of equality). This is the most popular definition of sustainability [20].

International standards, such as ISO 14001, provide a simple way of assuring that the activities of organizations are environmentally sustainability [21]. Furthermore, they promote environmental protection and pollution prevention from the point of view of a balance with socioeconomic aspects. The SA8000 standard is an initiative that allows organizations to demonstrate their ethical commitment to be managed in a socially sustainable manner. It brings transparency to their operations, achieving stakeholder confidence. It brings benefits to employees by ensuring improvements in their working conditions as well as a fairer, more equitable, and safer working environment [22]. The SA8000 standard is based on international labor principles and rights in accordance with the ILO (International Labour Organization), the Universal Declaration of Human Rights, and the Convention on the Rights of the Child. It includes requirements for child labor, forced and compulsory labor, health and safety, the right to organize and collective bargaining, discrimination, disciplinary measures, working hours, remuneration, management systems, and so forth. The SA8000 is an internationally accepted tool that aims to ensure a decent workplace in the adoption of CSR practices [23].

Furthermore, traceability and transparency should be included. Traceability records how things are made, while transparency ensures profits across the entire chain [24]. Transparency is a strong element of social responsibility because it can help ensure that no one in the chain is being abused. It is a revolution in our hyper-communicative societies [14]. Some supply chains pursue low wages and questionable social and environmental protection. In contrast, Pagell et al. [24] identified profitable 
cases that follow a different direction with local suppliers. Following the proposal by Carter et al. [25] depicted in Figure 1, purchasing should look for the best improvements with suppliers.

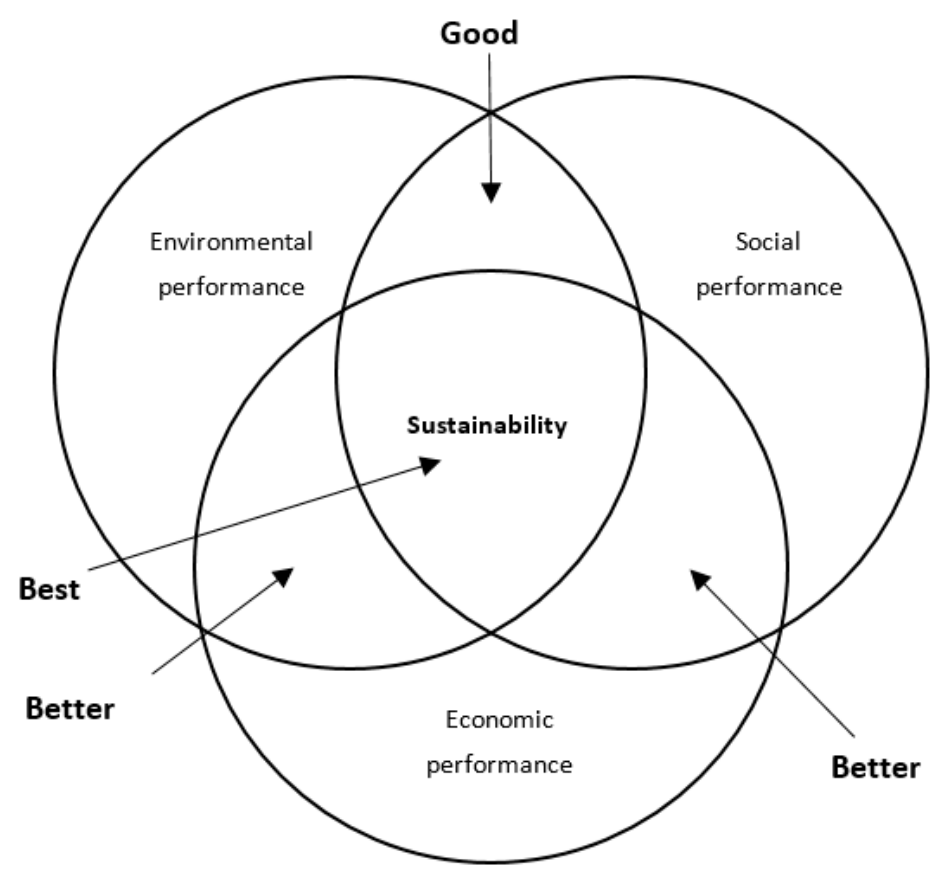

Figure 1. Sustainable improvements search area (Source: Adapted from Carter et al. [25]).

This paper helps to shed light on the steps to prioritize actions in supplier segmentation and the buyer's leadership in identifying suppliers to achieve a sustainable supply chain. The rest of the paper is structured as follows: Section 2 offers a systematic literature review on supplier segmentation and sustainable development; Section 3 provides some business evidence; Section 4 presents the proposed multi-criteria decision-making method; Section 5 reviews two practical cases; Section 6 provides the conclusions and paths for future works.

\section{A Systematic Review of the Literature on Supplier Segmentation and Sustainable Development}

In the 1990s, purchasing and supply chain management evolved from a traditional operational function into a strategic function. They are increasingly recognized by organizations as key business drivers $[26,27]$. Empirical evidence indicates that firms can indeed obtain competitive advantages by managing supplier relations [28-30]. This change has been accompanied by increasing attention from both managers and researchers on purchasing as a field of strategic interest [31].

Today, manufacturing companies work with hundreds of suppliers to manufacture their products. These suppliers provide materials with different values, qualities, and volumes. They are characterized by different features [32] and have different characteristics in terms of supplier relationship management. Differentiation is needed in managing supplier relationships. This requires some sort of classification [33]. A holistic view of supplier segmentation covering supply market conditions, product/service characteristics, supplier characteristics, buyer characteristics, and buyer-supplier relational factors [34] is advisable when analyzing this topic.

Supplier development is one of the most important supply chain-related activities for most firms working with multiple suppliers [32]. One of these strategic activities is supplier relationship management, which can be defined as the way relationships with suppliers are established, developed, and sustained. This classification makes it possible to choose the most suitable strategies for handling different segments of selected suppliers. 
The aim of supplier segmentation is to create a manageable number of supplier segments, thus reducing the number of strategies a company must develop [32]. Supplier segmentation maintains and enhances the position of the buying company in the marketplace [35]. Although this task seems simple, the problem is how to identify these segments.

Parasuraman [36] was one of the first to introduce the concept of supplier segmentation, naming it "vendor segmentation." Parasuraman describes a practical approach for this segmentation analysis as a stepwise procedure, outlining the potential benefits and limitations of using this approach.

One of the first authors to propose a systematic approach to supplier segmentation was Kraljic [37]. Kraljic proposed two dimensions: supply risk and profit impact. Supply risk is defined as the probability of an incident associated with inbound supply from individual supplier failures or the supply market. In this case, the outcome is either the inability of the purchasing firm to meet customer demand or threats to customer life and safety [38]. Profit impact is defined in terms of the volume purchased and the percentage of the total cost of purchases [39]. Using these dimensions, four segments are defined and strategies are suggested to manage the segments in different ways.

One of the fundamental problems is that different methods for supplier segmentation have been specified, all of which use different variables and neglect others. From a scientific perspective, the lack of an overarching framework including all key variables represents a serious gap. From a management perspective, this is a problem because it is hard to choose a method that contains all key variables.

In addition, supplier segmentation is performed assuming the static perspective proposed by Kraljic (i.e., suppliers are segmented at one point in time). However, in practice, a buyer-supplier relationship may involve many transactions that evolve over time.

Rezaei and Ortt [40] classified studies into three groups: (1) the process method, (2) the portfolio method, and (3) the involvement method to supplier segmentation. Furthermore, there are "pure" methods (process, portfolio, or involvement) and combination methods (portfolio-involvement). The "pure" methods appear first and the combination methods appear later:

(1) The process method identifies distinguishable segments of potential suppliers for each item to be purchased by an industrial company. These segments are based on characteristics that are closely related to the key characteristics of the company's own customer segments [36].

(2) The portfolio method classifies the materials or components that a firm can purchase. Two variables are considered: profit impact and supply risk. Based on these two variables, materials or components can be divided into four supply categories: (1) non-critical items (supply risk: low; profit impact: low), (2) leverage items (supply risk: low; profit impact: high), (3) bottleneck items (supply risk: high; profit impact: low), and (4) strategic items (supply risk: high; profit impact: high). Each category requires a specific supplier strategy [37]. However, positioning in the matrix in terms of supply risk and benefit impact is subjective; it does not take into account suppliers' reactions or joint development, nor does it encourage a joint working mentality [41]. Years later, Kraljic noted "the importance of trust in long-term relationships with suppliers. You need trust to create win-win" [42]. Other authors have also used the portfolio model by introducing other classification dimensions: Van Stekelenborg et al. [43] used control need of the internal market demand and control need of the external supply market as classification dimensions. Olsen et al. [44] used difficulty of managing the purchase situation and the strategic importance of the purchase as classification dimensions. Bensaou [45] used buyer's and supplier's specific investments as classification dimensions. Finally, Gelderman et al. [46] used supplier's and buyer's dependence as classification dimensions.

(3) According to the involvement method, firms should determine their core competencies as relevant core activities and non-core activities. Resources that relate to core activities are strategic resources, while those that relate to non-core activities are non-strategic resources. With this method, the level of involvement determines the type of relationship. Based on this classification, the authors suggest two types of buyer-supplier relationships [28]: 
(a) Durable arm's-length (quasi-market) relationships are suitable for the first class of inputs or resources, which are necessary but non-strategic.

(b) Strategic partnerships (quasi-hierarchies) are suitable for the second class of inputs or strategic inputs, which are important in differentiating the buyer's final product.

Later on, Rezaei et al. [47] proposed a portfolio method with two axes: capabilities and willingness. Within each axis, a broad measurable proposal to be weighted is included. The general management must select the most suitable measurable proposal. Some invited managers should evaluate the suppliers with these metrics. Then, the purchasing manager and CEO (Chief Executive Officer) select the most and least important criteria respectively for each level that serve to weight all evaluations on each axis. The weighting seeks to minimize the maximum difference between the absolute differences between the weight ratios.

Supplier segmentation should reflect supplier selection criteria. There are three kinds of supplier selection criteria: exchange-related criteria (referring to characteristics of the goods or activities that are provided by a supplier), supplier-related criteria (referring to the characteristics of the supplier), and relationship-related criteria (referring to the characteristics of the buyer-supplier relationship).

Since suppliers can perform differently with regard to the desired criteria, they need to be managed accordingly. Using these criteria to segment suppliers helps the buyers manage their suppliers more effectively. Ellram et al. [48] discussed the notion of increased emphasis on team responsibility for the purchasing function. Team participation should foster improved communication, awareness, and integration of the purchasing function with other functional groups in the firm. There are higher levels of team participation in purchasing when the function has a strategic orientation [49]. Johnson et al. [50] also found that the strategic role of purchasing is positively related to the greater use of internal cross-functional teams.

The method used to conduct the literature review was a systematic literature review [51-53]. The search keywords were "sustain*" and "supplier" and "segmentation" in WoS (Web of Science). The search returned 18 results. The search results that were not close to the target of this research were discarded. We then focused on the articles most closely related to our study, which examines how sustainability has been introduced in supplier segmentation. From there, we continued with the search using the snowball tool.

Recent segmentations account for the complexity of multivariable SCM. However, they do not identify the responsibilities of different functional areas within companies in managing suppliers. The weighting of the multiple variables is the choice of purchasing management, without being considered as a tool for internal coordination management. It is an important instrument for sustainable development.

\section{Business Evidence of Supplier Development}

Since the concept of the supply chain first appeared in 1982 [54], competition no longer occurs only among companies but also among their supply chains, which must be coordinated. In fact, firms must manage the improvement among the supply chain members [53]. One of the main business processes of SCM is supplier relationship management, which is focused on developing and strengthening relationships with suppliers [47]. The task of purchasing has progressed from an administrative function back in the 1960s to a strategic function today [41]. Buyers in a non-sophisticated purchasing function solve day-to-day problems with suppliers and spend their time mainly on clerical and administrative tasks. However, purchases have a greater bearing on final product cost, as shown in Table 1.

Therefore, SCM should be an important issue for companies. The current sophisticated purchasing function reports directly to top management [41], and even CEOs are directly involved in SCM. Outstanding SCM makes a big difference to companies. 
Table 1. Suppliers' bearing on the income statement.

\begin{tabular}{ccc}
\hline Type & $\%$ & Sector \\
\hline Manufactured goods & $50-70 \%$ & $\begin{array}{r}\text { Automotive, appliances, engineering, machinery and consumer } \\
\text { goods, advanced software }\end{array}$ \\
\hline Process industry & $60-85 \%$ & $\begin{array}{r}\text { Food, drugstore and cosmetics, pharmacy, iron and steel, cement, } \\
\text { glass, chemistry, gas, petroleum, mining }\end{array}$ \\
\hline Services & $60-90 \%$ & $\begin{array}{c}\text { Distribution, wholesalers, retailers, transportation, financial, } \\
\text { professional services, telephone }\end{array}$ \\
\hline Source: Adapted from Errasti-Opacua [55].
\end{tabular}

As an example, Walmart has a close relationship with its suppliers and looks for cooperation in the management of the value chain [56]. This approach goes against the traditional view, or the arm's-length model of supplier management, which advocates minimizing dependence on suppliers and maximizing bargaining power [57]. Walmart develops working relationships and shares information with its key suppliers [58]. Walmart suppliers are squeezed financially more than their counterparts, but they obtain larger market shares. Their profitability is greater than that of their counterparts [59]. Walmart simply does a better job of forging relationships that permit its suppliers to be more efficient when they get large.

In the automotive sector, there is a correlation between automaker trustworthiness with suppliers [60] and automaker market-share performance. Hyundai and Kia have increased their suppliers' trust while improving their U.S. market performance in the period from 2000 to 2009 [61]. The success of Japanese automakers has often been attributed to close supplier relationships [57]. They share more information and have better coordination, invest in dedicated assets with lower costs, improved quality, and speedier product development, and rely on trust to govern the relationship [62]. This is a highly efficient governance mechanism that minimizes transaction costs [63]. However, these types of relationships are costly to set up and maintain, and may reduce a customer's ability to switch away from inefficient suppliers [24]. However, it is compensated with fewer suppliers, requiring fewer buyers and with more long-term relationships. General Motors (GM) has traditionally employed roughly 8 to 10 times more people in procurement than Toyota [57]. The main U.S. automakers' share of the U.S. auto market fell from $64.7 \%$ to $43.6 \%$ between 2000 and 2009, while Japanese firms increased their market share from $21.2 \%$ to $36.8 \%$ and Korean firms also increased their market share from $2.2 \%$ to $6.9 \%$ [61]. Furthermore, the purchasing power strategy at GM of demanding massive cost reductions from their suppliers has worked in the short run, but has led to problems for GM [44]. Years later, GM remains the worst-ranked automaker by U.S. suppliers [64].

In the restaurant sector, McDonald's should be noted for its close relationships with suppliers, creating food towns comprising a bakery, meat plant, chicken plant, lettuce plant, fish plant, and distribution center [65]. McDonald's does business with strategic suppliers based on the commitment of an old-fashioned handshake (no formal contract) and mutual trust [66]. As its founder, Ray Kroc, once said in accordance with a long-term system-first philosophy [67], "what is good for the System is good for them". The System is identified as the three legs of their business: suppliers, restaurants, and McDonald's. As a McDonald's North America supply chain manager said, "in my tenure of 18 years at McDonald's, I can count the number of exits on one hand", in reference to suppliers [66]. Therefore, an important supplier development process must be implemented to maintain suppliers with the quality, service, cleanliness, and value (QSC \& V) required for the company. Long-term relationships with quality suppliers are necessary for sustainable development [68].

Among retailers, Mercadona offers an interesting case. Mercadona is a Spanish retailer ranked 47th by revenue in the Global Power of Retailing report [69]. It has been the leader in its market since the end of 2008 [70]. This is despite the fact that Carrefour, ranked 9th [69], entered the Spanish market in 1975 and Lidl (Schwarz Group), ranked 4th [69], entered the Spanish market in 1994. Mercadona also remains the leader on average in terms of the increase of its annual market share [71]. It is also the leader 
in terms of turnover by surface area [72]. In order to maintain that position, Mercadona has developed a close relationship with its suppliers, seeking cooperation, stability, mutual trust, and information sharing [73]. Mercadona has 2000 suppliers, of which approximately 110 are integrated suppliers, called "inter-suppliers" [74]. These inter-suppliers have indefinite contracts. Mercadona and its exclusive inter-suppliers dedicate substantial resources to joint research, product improvement, and supplier development, based on end customer requirements. The company model says that the end customer is the "boss" but the system needs the loyalty of employees, suppliers, society, and capital. This business model has embraced the values of CSR [75].

The buyer must continually compare and measure the situation against the market [57]. Anything that is not measured does not improve but gets worse. Purchasers must continually choose between using another supplier and helping suppliers improve their performance in order to become leaders. The former should be the last resort due to the direct costs involved in switching suppliers and the message of loss of confidence that it sends to the supplier portfolio. Cerealto Siro Food, Mercadona's inter-supplier since the start, is selling all its plants dedicated to Mercadona to third parties, due to changes in strategy with inter-suppliers that Mercadona has recently implemented [76]. Switching suppliers is a joint failure of the supplier and the buyer. A successful relationship must include trust, long-term commitment, adaptation, interdependence, cooperation, mutual objectives and incentives, social and structural links, respect, promises, shared values, and interaction (plant visits, audits, training, performance measurement, certification, and recognition) $[40,77,78]$. It should follow rules such as "focus on outcomes not transactions, on the what not the how, clearly defined desired outcomes, pricing with incentives, governance with insight" [79].

Trust grows over time and is embedded in the relationship itself. Trust cannot be traded in the marketplace and is very difficult for competitors to imitate [8]. The incentives should include being rewarded with increased business or a decline in order volumes [80]. Every three years, McDonald's redefines market sharing based on the monthly report [66].

Also, relationships require personal stability between buyers and sellers in the face of frequent job rotation due to compliance and bias in the industry [81]. Face-to-face is the richest medium [82] that the relationship requires. It is common in Toyota employee transfer with its main suppliers [57] and the regular visits by Mercadona's buyer to inter-suppliers. In this case, each buyer manages only two inter-suppliers [83]. Another example is provided by the permanent supplier resident engineers at Ford facilities.

\section{A Supplier Segmentation Proposal}

As the discussion so far has shown, purchasing can create a sustainable competitive advantage by enabling the promotion of open communication among supply chain partners and developing a long-term strategic relationship orientation to achieve mutual gains [41]. Sustainable solutions can be developed for stakeholders using a suitable segmentation for supplier development. The major objective of buyers is to "never stop our customer, the (production) plant", to satisfy customer requirements. The secondary goal is to achieve cost reduction objectives (Statement at the seminar "Experiencias de un comprador" ("Experiences of a buyer") Original Equipment Manufacturer (OEM) automotive buyer, 11 September 2017, at Universitat Politècnica de València, Alcoy). The latter ceases to matter if the first objective is not achieved. Therefore, the supplier segmentation should first concentrate on supplier risk management related to the impact on the company's future profits. Supply management is now a strategic objective that requires coordination from the CEO. The CEO should delegate control to the top management team related to their control areas. Therefore, the area managers should be responsible for their individual functional area within the entire supply chain. Supplier risk management should cover all areas of a company in supply chain monitoring. Each functional area of the company should define its metrics of the supply risk related to its area (Stage 1 in Figure 2). 


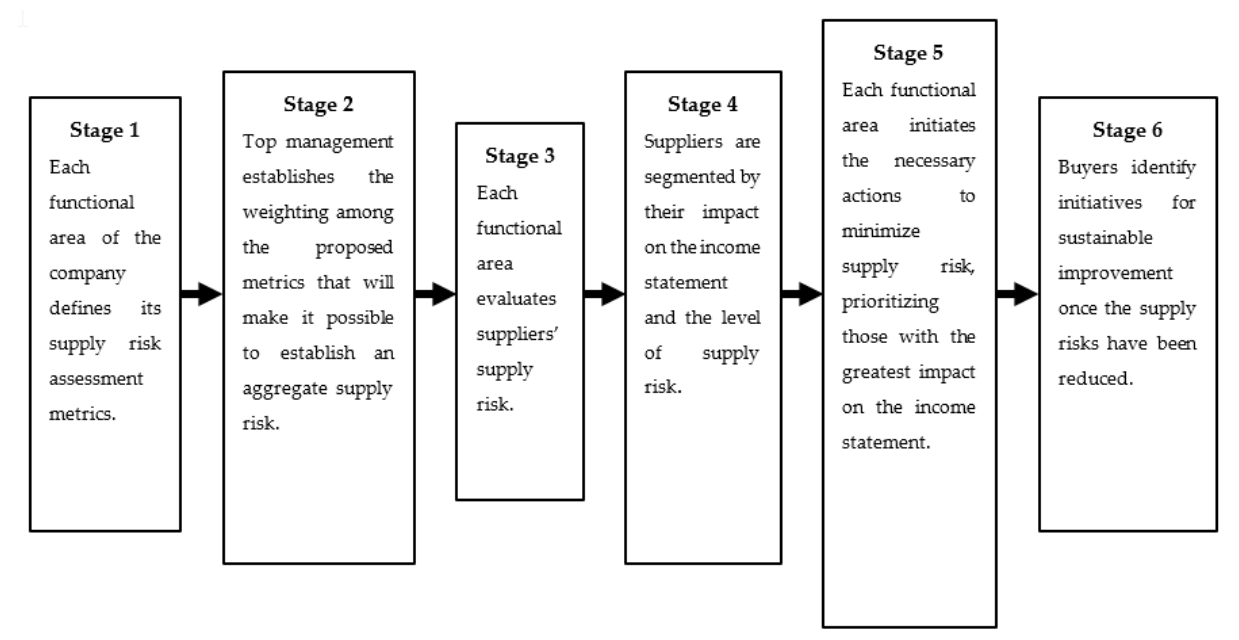

Figure 2. Supplier segmentation steps (Source: The authors).

Several areas, such as quality, engineering, and production, are most common to support suppliers' risk management. The supply risk management should be implemented by the management of each functional area. The aggregate supplier risk evaluation should be a weighted sum of each evaluation (Stage 2 in Figure 2). Top managers should define weight balancing that enables summing across different company functional areas (quality, finance, operations, human resources, etc.). The weighting allows different suppliers' functional views to be integrated. It also enables the integration of assessments of each functional area with respect to each supplier. These can be disqualifications or evaluations within a consensus scale. For example, the loss of a supplier's Q1 distinction, managed by the supplier's technical assistance (STA), prevents Ford buyers from releasing new purchase orders to that supplier. The different company areas evaluate suppliers' supply risk using their metrics (Stage 3 in Figure 2).

All functional areas should be included. The finance department should also monitor the supply chain. It is accepted in industry that the finance department sets a commercial limit on each customer related to insurance risk assessment companies. It should also be specified for suppliers. Other actions could be to establish a confirmation option that allows for better supplier financing. Supplier bankruptcies have had serious effects on the automotive sector, as in the case of Delphi or Collins and Aikman [84]. Human resources must oversee the development of employees in the supply chain. It should ensure adequate compliance with legislation, along with employee development. The improvement comes from the added value of each employee in the supply chain. Continuous improvement can only be implemented if there is a suitable working environment. Global adequate working conditions have a direct outcome on overall supply chain performance. A supplier strike action can stop the whole supply chain.

Environmental compliance and monitoring can also have an impact on the entire supply chain. The area responsible for environmental management must check that each supply chain member takes the correct actions. A third-tier supplier shut down for violating China's environmental regulations has had an effect on 49 OEM assembly plants in the case of Schaeffler [85]. Supply chain risk management must be extended beyond the first-tier suppliers. On 11th March 2011, an earthquake seriously affected the Naka microcontroller plant. The company was exclusively supplying many automotive suppliers, including both Toyota's integrated suppliers and Honda's entire panel. Following this incident, Nissan took two months to recover, with Toyota taking three months and Honda four months to recover [86].

Even commercial departments need adequate supplier development to facilitate sales. In certain cases, suppliers need a sales volume that the supply chain does not allow, so the supplier must fill it with other customers, which should be evaluated by the commercial team. In some cases analyzed by Pagell et al. [87], customers have helped suppliers in the supply of natural and organic markets to 
competitors. McDonald's allowed Klosterman Bakeries in Puerto Rico to sell to competitors, as long as it could make a profit at the local plant [66].

Suppliers could be segmented by their impact on the income statement and the calculated level of supply risk (Stage 4 in Figure 2). Each company area should then initiate the necessary actions to minimize supply risk in its related functional area, prioritizing suppliers with the greatest impact on the income statement (Stage 5 in Figure 2). Following the names used in Kraljic's proposal [37], strategic suppliers should receive full organizational support to minimize the supply risk, followed by bottleneck suppliers.

Once the risk reduction actions have been implemented, buyers must perform the continuous search for improvements within their functions (Stage 6 in Figure 2). The improvement could be a cost reduction as well as supply chain sustainability. Improvements, as demanded by stakeholders, must involve economic, social, and environmental sustainability or any one of these, as long as it does not threaten the others or the supply risk. Getting the best (lowest) price may mean a decrease in prosperity for the supplier and, by extension, the supplier's employees and the communities where the supplier operates, creating a supply risk [24]. Economic sustainability should be considered in the improvement. Leverage and non-critical suppliers are where buyers must perform the continuous search for sustainable improvements.

\section{Application of the Supplier Segmentation Proposal to Real Cases}

Two case studies are presented. The research followed the case study method [88]. The research focus was to shed light on the steps in applying the proposed segmentation and leadership in the development of suppliers to achieve a sustainable supply chain. Two cases were selected for the research, with the understanding that case study research depends on investigative observation [89]. The first case is a company that is seeking to improve its purchasing management and sustainable supplier development and that is applying the proposed segmentation steps. The second presents the impressions of a manager involved in a purchasing strategy of focusing purchases on a single supplier in the automotive sector when following the proposed steps of supplier segmentation. The data were collected from the work done on the segmentation of the supplier portfolio [82] and from interviews with managers who participated in the process. The data were analyzed and presented to independent experts to validate the contribution.

\subsection{Application of the Supplier Segmentation Proposal}

To illustrate the steps shown in Figure 2, the phases of a segmentation proposal in a railway manufacturing company are presented [90]. The material requirements represent $49 \%$ of the company's total costs, according to its 2017 profit and loss account. The work was started on productive purchasing, leaving non-productive purchasing and external production purchasing for later. The involvement of all the departments was requested by the top management to establish the suppliers' risk evaluation metrics. The established consensus measurements can be seen in Table 2 (Stage 1 in Figure 2). The sales, operations, after-sales, information systems, and human resources departments declined to participate. It was relegated to a later stage to incorporate more areas in the supply risk assessment. Each department highlighted the most appropriate measurement in the supply risk assessment from the perspective of its functional area.

The calculation procedure was defined, as well as data origin, measurement units, frequency in which they were to be reported, and department. For example, purchasing metrics were defined as "supplier alternatives" based on the number of approved suppliers for each product family with a quarterly frequency. They were then transformed into a risk level from 0 to 1 . All indicators were defined on a range from 0 to 1 . At the top management level, weighting criteria for all indicators were agreed upon to obtain a global risk indicator for each supplier. In this case, it was agreed that all measurements should have equivalent weights (Stage 2 in Figure 2). Each department evaluated the suppliers' supply risk with their metrics (Stage 3 in Figure 2). 
Table 2. Measurements and department.

\begin{tabular}{cc}
\hline Measure & Department \\
\hline Financial capacity & Finance \\
Supplier alternatives & Purchasing \\
Delivery time & Logistics \\
Technological capacity & Engineering \\
Negotiation time requirement & Purchasing \\
Quality indicator & Quality \\
\hline
\end{tabular}

Source: The authors.

With respect to future profit impact, the budgets established for each item's family in the vehicle budget were collected. This value made it possible to segment suppliers that were expected to have a greater impact on the supply risk for the vehicle under analysis.

Based on the two measurable aggregates of supply risk and profit impact, initial segmentation of the company's supplier portfolio was carried out (Stage 4 in Figure 2). This segmentation, which is in line with Kraljic's proposal [37], makes it possible to define priority strategies. It allows identification of suppliers where risk management actions should be prioritized by all departments. First, those in the strategic quadrant because of their budget impact should be prioritized, followed by those in the bottleneck quadrant. This is depicted in Figure 3. Each dot represents the position of a supplier item's family in terms of supply chain risk and its impact on future profit in the vehicle budget.

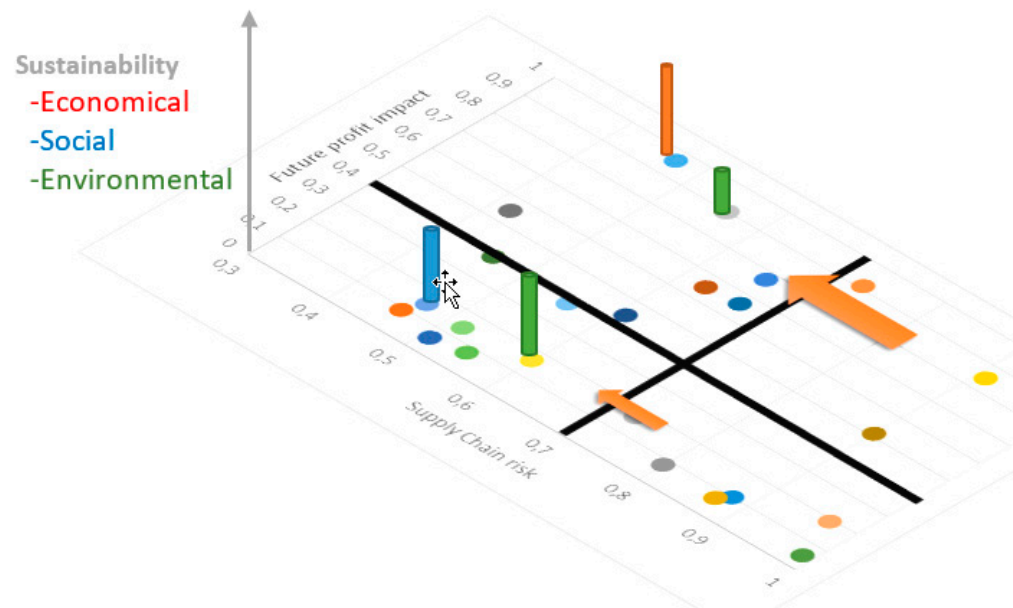

Figure 3. Sustainable improvement projects. Each dot represents the position of a supplier item's family. The columns are the new sustainable projects identified by the purchasing department (Source: The authors).

Once the suppliers with high supply risk have been identified, each area should take the most appropriate actions to reduce that overall risk (Stage 5 in Figure 2). The supply risk management should be the first objective. Once the riskiest suppliers have been identified and risk management has been implemented, the buyer can then address other challenges.

The buyer should identify suppliers with a low risk level that can contribute to supply chain sustainability (Stage 6 in Figure 2). The improvements can lead to advances in economic, social, or environmental sustainability. Improvements may be in all three dimensions or just in one or two of them, as long as it does not threaten the other dimensions. The buyer identifies such potential improvements by prioritizing those with added value to stakeholders. Figure 3 shows how certain projects with specific suppliers have been identified as sustainability improvements that should shape the next steps by buyers. The columns in Figure 3 represent these sustainable improvements. 


\subsection{MAThread ${ }^{\circledR}$ in Ford Europe}

MAThread ${ }^{\circledR}$ technology [91] was introduced in Ford Europe between 2003 and 2004, making thread seizure impossible. The threading of a screw requires manual pre-threading before tightening (common at the time in the Saarlouis and Cologne plants in Germany and the Genk plant in Belgium), or else repairs to the thread would be needed if such a seizure occurred in the Valencia plant (Spain).

Years earlier, the purchasing department for joining elements across Europe, led by buyers at the Valencia plant, had consolidated all joining elements in a single supplier (nuts, screws, clips, wall bushings, etc.). In addition, this new supplier had been asked to take over the delivery of all components to assembly plants in Kanban and would be paid for each completed car. The two main suppliers, one for screws and one for plastic fasteners, created the new supplier. The start-up took place first in the Genk plant and then spread to other plants. The change involved incidents that were solved by improving service, quality, and cost, mainly reducing supply risks. Figure 4 shows a representation that should have been made at that time. A single supplier started performing the service of the previous suppliers. It first improved the supply risk and then offered sustainable improvements.

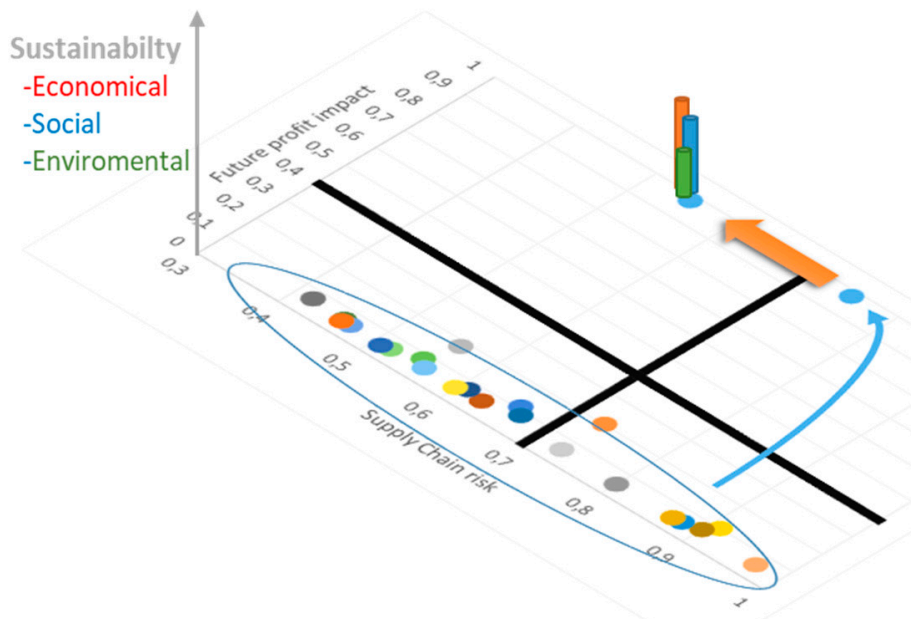

Figure 4. Sustainable improvement project of the joint elements.

Once the new operation had stabilized, the supplier proposed the introduction of the new MAThread ${ }^{\circledR}$ technology. The new supplier had resident engineers in the assembly and development plants, along with quality and customer service personnel. In this new situation of proximity, continuous improvements could be implemented for component conditioning, assembly tools, and so on to improve the work of operators at Ford plants in a social sense. However, the new threading tip required a change of product, so the buyers invited vehicle engineers. The new technology was presented by suppliers to the buyer and began to be analyzed by the development team, which was based in the Valencia plant at the time. The design team was for the Ford Ka, a vehicle whose production was planned to end in the coming years (Ford Ka was manufactured in the Valencia plant from 1996 to 2007). The improvement was first introduced in this vehicle and later in the other vehicles that the group had in Europe. The improvement entailed an increase in product costs but led to major savings in the total cost of the final product. Other design improvements, with lighter materials and surface coatings that led to environmental improvements, were implemented as they were presented in the sector [92]. In this case, only purchasing, STA, and material handling actively participated in the supply risk reduction and sustainable improvement identification. It was concluded that if others areas had been involved, it may have accelerated other sustainable improvements such as the later kitting implementation. 


\section{Results and Conclusions}

This paper presents a novel approach to supplier development. This approach is based on a supplier segmentation method that prioritizes risk management as a prerequisite for sustainable development of the supply chain. The steps of this supplier segmentation method respond to the current polarization between the pursuit of sustainability and security in the supply chain. They highlight the importance of proximity and face-to-face relationships in economic, social, and environmental sustainability. The need to review functional managers' responsibilities across the entire supply chain, beyond the company itself, has also been highlighted. Supplier management must be handled by different functional areas given the importance of supply chain sustainability as accepted under CSR. Supplier development should be guided by the improvement of the different sustainability dimensions (economic, social, and environmental) as demanded by the company's stakeholders.

The continuous improvement in supply chain sustainability and not only in cost reduction [93,94] is the innovation tool that is required to support the supplier segmentation method presented in this paper. Pagell et al. [87] observed that a cost-constrained vision of Lean did not achieve the breakthrough in the company to extol sustainability. The change of continuous improvement in sustainability demanded by the company's stakeholders enables suppliers and the supply chain as a whole to develop. A truly sustainable supply chain is a supplier that is willing to keep doing business forever [24].

The proposal for segmentation and the review of responsibilities in the supply chain have been presented for two specific cases. The initial tendency to decline to participate by several departments, despite their importance in the SCM, has been highlighted. It is also stressed that if other areas were involved, it may have accelerated other sustainable improvements. Future research should analyze more case studies in different scenarios following the proposed steps to design a basis for the theory [89]. Furthermore, it would also be useful to evaluate the relationship between the necessary buyers' leadership in supplier development and sustainable supply chain leadership. In addition, the new role of managers in the supply chain requires more in-depth analysis to explore its consequences.

Author Contributions: Conceptualization, G.R.-S. and S.E.-M.; methodology, G.R.-S. and S.E.-M.; validation, G.R.-S., S.E.-M. and C.R.-A.; formal analysis, G.R.-S. and S.E.-M.; investigation, G.R.-S. and S.E.-M.; resources, G.R.-S. and S.E.-M.; data curation, G.R.-S. and S.E.-M.; writing-original draft preparation, G.R.-S., S.E.-M. and C.R.-A.; writing - review and editing, G.R.-S., S.E.-M. and C.R.-A.; visualization, G.R.-S., S.E.-M. and C.R.-A.; supervision, G.R.-S., S.E.-M. and C.R.-A.; project administration, G.R.-S., S.E.-M. All authors have read and agreed to the published version of the manuscript.

Funding: This research received no external funding.

Conflicts of Interest: The authors declare no conflict of interest.

\section{References}

1. Rabieh, M.; Fadaei Rafsanjani, A.; Babaei, L.; Esmaeili, M. Sustainable Supplier Selection and Order Allocation: An Integrated Delphi Method, Fuzzy TOPSIS and Multi-Objective Programming Model. Sci. Iran. 2018, 26, 2524-2540. [CrossRef]

2. Joyce, A.; Paquin, R.L. The triple layered business model canvas: A tool to design more sustainable business models. J. Clean. Prod. 2016, 135, 1474-1486. [CrossRef]

3. Barney, J.B. Introduction to the special issue on the resource-based view of the firm. J. Manag. 1991, 17, 97-99.

4. Wernerfelt, B. A resource-based view of the firm. Strateg. Manag. J. 1984, 5, 171-180. [CrossRef]

5. Barney, J.B. Is the resource-based "view" a useful perspective for strategic management research? Yes. Acad. Manag. Rev. 2001, 26, 41-56. [CrossRef]

6. Eisenhardt, K.M.; Furr, N.R.; Bingham, C.B. CROSSROADS-Microfoundations of Performance: Balancing Efficiency and Flexibility in Dynamic Environments. Organ. Sci. 2010, 21, 1263-1273. [CrossRef]

7. Teece, D.J. The Foundations of Enterprise Performance: Dynamic and Ordinary Capabilities in an (Economic) Theory of Firms. Acad. Manag. Perspect. 2014, 28, 328-352. [CrossRef] 
8. Gold, S.; Seuring, S.; Beske, P. Sustainable supply chain management and inter-organizational resources: A literature review. Corp. Soc. Responsib. Environ. Manag. 2010, 17, 230-245. [CrossRef]

9. Walker, H.; Jones, N. Sustainable supply chain management across the UK private sector. Supply Chain Manag. An Int. J. 2012, 17, 15-28. [CrossRef]

10. North, D.C. Institutions, Institutional Change and Economic Performance; Cambridge University Press: Cambridge, UK, 1990; ISBN 9780521394161.

11. North, D.C. Understanding the Process of Economic Change; Princeton University Press: Princeton, NJ, USA, 2005; ISBN 9780691145952.

12. Bowen, H.R. Social Responsibilities of the Businessman; Harper \& Row: New York, NY, USA, 1953.

13. Carroll, A.B. Corporate Social Responsibility. Bus. Soc. 1999, 38, 268-295. [CrossRef]

14. Elkington, A.R. Cannibals with Forks: The Triple Bottom Line of 21st Century Business; Capstone Publishing Ltd.: Oxford, UK, 1997; ISBN 1-900961-27-X.

15. Xia, Y. Competitive strategies and market segmentation for suppliers with substitutable products. Eur. J. Oper. Res. 2011, 210, 194-203. [CrossRef]

16. Seuring, S.; Müller, M. From a literature review to a conceptual framework for sustainable supply chain management. J. Clean. Prod. 2008, 16, 1699-1710. [CrossRef]

17. Bai, C.; Rezaei, J.; Sarkis, J. Multicriteria Green Supplier Segmentation. IEEE Trans. Eng. Manag. 2017, 64, 515-528. [CrossRef]

18. Akhavan, R.M.; Beckmann, M. A configuration of sustainable sourcing and supply management strategies. J. Purch. Supply Manag. 2017, 23, 137-151. [CrossRef]

19. UNCSD Industry and Sustainable Development-6th Session. Available online: http://www.un.org/ga/ search/view_doc.asp?symbol=E/CN.17/1998/4\&Lang=E (accessed on 15 December 2019).

20. Vivas, R.; Sant'anna, Â.; Esquerre, K.; Freires, F. Measuring Sustainability Performance with Multi Criteria Model: A Case Study. Sustainability 2019, 11, 6113. [CrossRef]

21. AENOR Certificación ISO 14001 Sistemas de Gestión Ambiental. Available online: https://www.aenor.com/ certificacion/medio-ambiente/gestion-ambiental (accessed on 23 February 2020).

22. AENOR Certificación SA 8000. Available online: https://www.aenor.com/certificacion/responsabilidadsocial/sa-8000-empresa-saludable (accessed on 23 February 2020).

23. Merli, R.; Preziosi, M.; Massa, I. Social Values and Sustainability: A Survey on Drivers, Barriers and Benefits of SA8000 Certification in Italian Firms. Sustainability 2015, 7, 4120. [CrossRef]

24. Pagell, M.; Wu, Z.; Wasserman, M.E. Thinking differently about purchasing portfolios: An assessment of sustainable sourcing. J. Supply Chain Manag. 2010, 46, 57-73. [CrossRef]

25. Carter, C.R.; Liane Easton, P. Sustainable supply chain management: Evolution and future directions. Int. J. Phys. Distrib. Logist. Manag. 2011, 41, 46-62. [CrossRef]

26. Cammish, R.; Keough, M. A Strategic Role for Purchasing. Available online: https: //go.gale.com/ps/anonymous?id=GALE\%7CA11739695\&sid=googleScholar\&v=2.1\&it=r\&linkaccess= abs\&issn $=00475394 \& \mathrm{p}=$ AONE\&sw $=\mathrm{w}$ (accessed on 15 November 2019).

27. Van Weele, A.J. Purchasing and Supply Chain Management; Cengage, Ed.; Annabel Ainscow: Andover, UK, 2018; ISBN 9781473749443.

28. Dyer, J.H. Specialized supplier networks as a source of competitive advantage: Evidence from the auto industry. Strateg. Manag. J. 1996, 17, 271-291. [CrossRef]

29. Mol, M. Outsourcing, Supplier Relations and Internationalisation: Global Sourcing Strategy as a Chinese Puzzle; Erasmus University Rotterdam: Rotterdam, The Netherlands, 2001; ISBN 9058920143.

30. Chen, I.J.; Paulraj, A.; Lado, A.A. Strategic purchasing, supply management, and firm performance. J. Oper. Manag. 2004, 22, 505-523. [CrossRef]

31. Dubois, A.; Pedersen, A.C. Why relationships do not fit into purchasing portfolio models a comparison between the portfolio and industrial network approaches. Eur. J. Purch. Supply Manag. 2002, 8, 35-42. [CrossRef]

32. Rezaei, J.; Fallah Lajimi, H. Segmenting supplies and suppliers: Bringing together the purchasing portfolio matrix and the supplier potential matrix. Int. J. Logist. Res. Appl. 2019, 22, 419-436. [CrossRef]

33. Lilliecreutz, J.; Ydreskog, L. Supplier Classification as an Enabler for Differentiated Purchasing Strategy. Global Purchasing and Supply Chain Management. In Best Practice Procurement; Erridge, A., Fee, R., Mcilroy, J., Eds.; Gower Publishing Limited: Aldershot, UK, 2001; pp. 66-74, ISBN 0566083663. 
34. Day, M.; Magnan, G.M.; Moeller, M.M. Evaluating the bases of supplier segmentation: A review and taxonomy. Ind. Mark. Manag. 2010, 39, 625-639. [CrossRef]

35. Svensson, G. Supplier segmentation in the automotive industry: A dyadic approach of a managerial model. Int. J. Phys. Distrib. Logist. Manag. 2004, 34, 12-38. [CrossRef]

36. Parasuraman, A. Vendor segmentation: An additional level of market segmentation. Ind. Mark. Manag. 1980, 9, 59-62. [CrossRef]

37. Kraljic, P. Purchasing Must Become Supply Management. Harward Bus. Rev. Bost. 1983, 61, 109-117. [CrossRef]

38. Zsidisin, G.A.; Ellram, L.M. An Agency Theory Investigation of Supply Risk M anagement. J. Supply Chain Manag. 2003, 39, 15-27. [CrossRef]

39. Lee, D.M.; Drake, P.R. A portfolio model for component purchasing strategy and the case study of two South Korean elevator manufacturers. Int. J. Prod. Res. 2010, 48, 6651-6682. [CrossRef]

40. Rezaei, J.; Ortt, R. A multi-variable approach to supplier segmentation. Int. J. Prod. Res. 2012, 50, $4593-4611$. [CrossRef]

41. Gelderman, C.J.; Van Weele, A.J. Purchasing portfolio models: A critique and update. J. Supply Chain Manag. 2005, 41, 19-27. [CrossRef]

42. Keith, B.; Vitasek, K.; Manrodt, K.; Kling, J. Strategic Sourcing in the New Economy: Harnessing the Potential of Sourcing Business Models for Modern Procurement; Palgrave Macmillan: London, UK, 2015; ISBN 9781137552181.

43. Van Stekelenborg, R.H.; Kornelius, L. A diversified approach towards purchasing and supply: Evaluation of production management methods. In Proceedings of the Evaluation of Production Management Methods: IFIP WG 5.7 Working Conference, Gramado, Brazil, 21-24 March 1994.

44. Olsen, R.F.; Ellram, L.M. A portfolio approach to supplier relationships. Ind. Mark. Manag. 1997, 26, 101-113. [CrossRef]

45. Bensaou, B.M. Portolios of buyer-supplier relationships. Sloan Manag. Rev. Summer 1999, 40, 35.

46. Gelderman, C.J.; Van Weele, A.J. New perspectives on Kraljic's purchasing portfolio approach. In Proceedings of the 9th International IPSERA Conference and the Third Annual North American Research Symposium on Purchasing and Supply Chain Management, Toronto, ON, Canada, 24-27 May 2000.

47. Rezaei, J.; Wang, J.; Tavasszy, L. Linking supplier development to supplier segmentation using Best Worst Method. Expert Syst. Appl. 2015, 42, 9152-9164. [CrossRef]

48. Ellram, L.M.; Pearson, J.N. The Role of the Purchasing Function: Toward Team Participation. Int. J. Purch. Mater. Manag. 1993, 29, 2-9. [CrossRef]

49. Giunipero, L.C.; Vogt, J.F. Empowering the Purchasing Function: Moving to Team Decisions. Int. J. Purch. Mater. Manag. 1997, 33, 8-15. [CrossRef]

50. Johnson, P.F.; Klassen, R.D.; Leenders, M.R.; Fearon, H.E. Determinants of purchasing team usage in the supply chain. J. Oper. Manag. 2002, 20, 77-89. [CrossRef]

51. Kitchenham, B.; Pearl Brereton, O.; Budgen, D.; Turner, M.; Bailey, J.; Linkman, S. Systematic literature reviews in software engineering-A systematic literature review. Inf. Softw. Technol. 2009, 51, 7-15. [CrossRef]

52. Rius-Sorolla, G.; Maheut, J.; Estelles-Miguel, S.; Garcia-Sabater, J.P. Protocol: Systematic Literature Review on coordination mechanisms for the mathematical programming models in production planning with decentralized decision making. WPOM-Working Pap. Oper. Manag. 2017, 8, 22. [CrossRef]

53. Rius-Sorolla, G.; Maheut, J.; Estellés-Miguel, S.; Garcia-Sabater, J.P. Coordination mechanisms with mathematical programming models for decentralized decision-making: a literature review. Cent. Eur. J. Oper. Res. 2020, 28, 61-104. [CrossRef]

54. Cooper, M.C.; Lambert, D.M.; Pagh, J.D. Supply Chain Management: More Than a New Name for Logistics. Int. J. Logist. Manag. 1997, 8, 1-14. [CrossRef]

55. Errasti-Opacua, A. Gestión de compras en la empresa; Piramide: Madrid, Spain, 2012; ISBN 978-84-368-2724-8.

56. Colla, E.; Dupuis, M. Research and managerial issues on global retail competition: Carrefour/Wal-Mart. Int. J. Retail Distrib. Manag. 2002, 30, 103-111. [CrossRef]

57. Dyer, J.H.; Cho, D.S.; Cgu, W. Strategic Supplier Segmentation: The Next “Best Practice” in Supply Chain Management. Calif. Manage. Rev. 1998, 40, 57-77. [CrossRef]

58. Walton, R. Wal-Mart, Supplier-Partners, and the buyer power issue. Antitrust Law J. 2005, 72, 509-527.

59. Bloom, P.N.; Perry, V.G. Retailer power and supplier welfare. J. Retail. 2001, 77, 379-396. [CrossRef]

60. Müller, H.E. Supplier integration: An international comparison of supplier and automaker experiences. Int. J. Automot. Technol. Manag. 2009, 9, 18-39. [CrossRef] 
61. Dyer, J.; Chu, W. The determinants of trust in supplier-automaker relations in the US, Japan, and Korea: A retrospective. J. Int. Bus. Stud. 2011, 42, 28-34. [CrossRef]

62. Dyer, J.H.; Chu, W. The Determinants of Trust in Supplier-Automaker Relationships in the U.S., Japan and Korea. J. Int. Bus. Stud. 2000, 31, 259-285. [CrossRef]

63. Dyer, J.H.; Chu, W. The Role of Trustworthiness in Reducing Transaction Costs and Improving Performance: Empirical Evidence from the United States, Japan, and Korea. Organ. Sci. 2003, 14, 57-68. [CrossRef]

64. Kelleher, J.B. GM Ranked Worst Automaker by U.S. Suppliers: Survey Reuters. Available online: https://www.reuters.com/article/us-gm-suppliers-survey/gm-ranked-worst-automaker-by-u-s-supplierssurvey-idUSBREA4B01I20140512 (accessed on 5 March 2020).

65. Ritchie, P. McDonald's: A Winner through Logistics. Int. J. Phys. Distrib. Logist. Manag. 1990, 20, 21-24. [CrossRef]

66. Vitasek, K.; Manrodt, K.B.; Kling, J. Vested: How P \& G, McDonald's, and Microsoft Are Redefining Winning in Business Relationships; Palgrave Macmillan: New York, NY, USA, 2012; ISBN 9780230341708.

67. McDonald's Our History. Available online: https://www.mcdonalds.com/us/en-us/about-us/our-history.html (accessed on 29 February 2020).

68. Xing, X.; Liu, T.; Wang, J.; Shen, L.; Zhu, Y. Environmental Regulation, Environmental Commitment, Sustainability Exploration/Exploitation Innovation, and Firm Sustainable Development. Sustainability 2019, 11, 6001. [CrossRef]

69. Deloitte Global Powers of Retailing 2018. Available online: https://www2.deloitte.com/ni/es/pages/consumerbusiness/articles/global-powers-of-retailing-2018.html (accessed on 29 February 2020).

70. Ton, Z.; Harrow, S. Mercadona. Available online: https://ssrn.com/abstract=1607757 (accessed on 1 March 2020).

71. Valencoso, C. Balance Gran Consumo 2016. Available online: https://www.kantarworldpanel.com/es/ Noticias/El-Gran-Consumo-cae-en-2016\#downloadThankyou (accessed on 3 December 2018).

72. Blanco-Callejo, M.; de Pablos-Heredero, C. Co-innovation at Mercadona: A radically different and unique innovation model in the retail sector. J. Bus. Retail Manag. Res. 2019, 13. [CrossRef]

73. Calabrese, A.; Scoglio, F. Reframing the past: A new approach in service quality assessment. Total Qual. Manag. Bus. Excell. 2012, 23, 1329-1343. [CrossRef]

74. Albors-Garrigos, J. Bringing your customers to the lab: Barriers and facilitators for consumer coinnovation. In Proceedings of the 2015 Portland International Conference on Management of Engineering and Technology (PICMET); IEEE: Piscataway, NJ, USA, 2015; Volume 2015, pp. 689-698.

75. Mercadé-Melé, P.; Molinillo-Jiménez, S.; Fernández-Morales, A. Influencia de las prácticas de responsabilidad social corporativa en la actitud del consumidor: análisis comparado de Mercadona, Carrefour y Eroski/Influence of the corporate social responsibility practices in the consumer attitude: A comparative analysis. Rev. Empres. Fam. 2014, 4, 73. [CrossRef]

76. Zaragozá, J.L. Siro acelera su desconexión de Mercadona con la venta de la planta de Navarrés. Available online: https://www.levante-emv.com/economia/2019/11/06/siro-acelera-desconexion-mercadonaventa/1941206.html?utm_medium=rss (accessed on 6 March 2020).

77. Harris, L.C.; O'Malley, L.; Patterson, M. Professional interaction: Exploring the concept of attraction. Mark. Theory 2003, 3, 9-36. [CrossRef]

78. Vitasek, K.; Ledyard, M.; Manrodt, K. Getting to We: A New Negotiating Model. In Vested Outsourcing: Five Rules That Will Transform Outsourcing; Palgrave Macmillan US: New York, NY, USA, 2013; pp. 177-184, ISBN 978-1-137-32118-3.

79. Vitasek, K.; Manrodt, K. Vested outsourcing: A flexible framework for collaborative outsourcing. Strateg. Outsourcing An Int. J. 2012, 5, 4-14. [CrossRef]

80. Krause, D.R.; Scannell, T.V.; Calantone, R.J. A Structural Analysis of the Effectiveness of Buying Firms' Strategies to Improve Supplier Performance. Decis. Sci. 2000, 31, 33-55. [CrossRef]

81. Zimmer, K.; Fröhling, M.; Schultmann, F. Sustainable supplier management-A review of models supporting sustainable supplier selection, monitoring and development. Int. J. Prod. Res. 2015, 54, 1412-1442. [CrossRef]

82. Wynstra, F.; Pierick, E. Ten Managing supplier involvement in new product development: A portfolio approach. Eur. J. Purch. Supply Manag. 2000, 6, 49-57. [CrossRef]

83. Audicana Arcas, J. Mercadona-Conservas Ubago: The Intersupplier Concept. Available online: https://www. santelmo.org/mercadona-conservas-ubago-the-intersupplier-concept/4971 (accessed on 15 November 2019).

84. Swinney, R.; Netessine, S. Long-Term Contracts Under the Threat of Supplier Default. Manuf. Serv. Oper. Manag. 2009, 11, 109-127. [CrossRef] 
85. Zhu, W.; Wang, Z. The collaborative networks and thematic trends of research on purchasing and supply management for environmental sustainability: A bibliometric review. Sustainability 2018, 10, 1510. [CrossRef]

86. Matsuo, H. Implications of the Tohoku earthquake for Toyota's coordination mechanism: Supply chain disruption of automotive semiconductors. Int. J. Prod. Econ. 2015, 161, 217-227. [CrossRef]

87. Pagell, M.; Wu, Z. Building a more complete theory of sustainable supply chain management using case studies of 10 exemplars. J. Supply Chain Manag. 2009, 45, 37-56. [CrossRef]

88. Stuart, I.; McCutcheon, D.; Handfield, R.; McLachlin, R.; Samson, D. Effective case research in operations management: a process perspective. J. Oper. Manag. 2002, 20, 419-433. [CrossRef]

89. Eisenhardt, K.M. Building Theories from Case Study Research. Acad. Manag. Rev. 1989, 14, 532-550. [CrossRef]

90. Navarro Alonso, G. Análisis de la Gestión de Compras y Aplicación de la Teoría de Kraljic Para una Empresa Ferroviaria; Universitat Politècnica de València: Valencia, Spain, 2019.

91. MAThread MAThread. Available online: https://mathread.com/ (accessed on 12 March 2020).

92. Nuñez, M. Constant evolution in fasterners. AutoRevista 2015, 2303, 100-115.

93. Garcia-Sabater, J.J.; Marín-Garcia, J.A. Can we still talk about continuous improvement? Rethinking enablers and inhibitors for successful implementation. Int. J. Technol. Manag. 2011, 55, 28. [CrossRef]

94. Paipa-Galeano, L.; Bernal-Torres, C.A.; Agudelo Otálora, L.M.; Jarrah Nezhad, Y.; González-Blanco, H.A. Key lessons to maintain continuous improvement: A case study of four companies. J. Ind. Eng. Manag. 2020, 13, 195. [CrossRef]

(C) 2020 by the authors. Licensee MDPI, Basel, Switzerland. This article is an open access article distributed under the terms and conditions of the Creative Commons Attribution (CC BY) license (http://creativecommons.org/licenses/by/4.0/). 